\title{
Local socio-economic effects of protected area conservation: The case of Maromizaha forest, Madagascar
}

\author{
Rose Marie Sissie Randrianarison', Andry Rajaonson', \\ José Myriel Ralison", Zoheritsimba Rabemananjarall', \\ Tahina Dandara Andrianantenainalv, Jules Rabearisonv, \\ Jonah Ratsimbazafyvi
}

\author{
Correspondence: \\ Rose Marie Sissie Randrianarison \\ Groupe d'Etude et de Recherche sur les Primates de Madagascar \\ (GERP), Département de Paléontologie et d'Anthropologie Bio- \\ logique (DPAB), Faculté des Sciences, Université d'Antananarivo. \\ Madagascar \\ E-mail: sissienarda@yahoo.fr
}

\section{RÉSUMÉ}

La vision « Madagascar naturellement » a été élaborée pour tripler la superficie des Aires Protégées de Madagascar en la portant de 1,7 millions d'hectares à 6 millions d'hectares avant 2008 afin d'assurer le sauvegarde du patrimoine naturel et le bien-être des Hommes. La forêt de Maromizaha avait été retenue par le Ministère de l'Environnement de l'Ecologie et des Forêts pour devenir une Nouvelle Aire Protégée (NAP) depuis 2008. Ce Ministère a nommé un délégataire, le Groupe d'Etude et de Recherche sur les Primates de Madagascar (GERP). L'une des stratégies du GERP est d'améliorer les moyens de subsistance de la population locale vivant à la périphérie de l'Aire Protégée de Maromizaha afin de réduire leur dépendance des ressources naturelles prélevées dans l'aire protégée. En avril 2014, le GERP a organisé une enquête préliminaire rapide sur la situation socio-économique des ménages pour comparer les principales activités génératrices de revenus, le niveau scolaire de la population locale en 2008 et en 2014, et le niveau de leurs connaissances sur les bienfaits de la conservation. Les méthodes de collecte de données ont été basées sur les questions filtre et le focus group. Les données analysées montrent que les principales activités génératrices de revenus en 2014 provenaient de l'agriculture(70\%) et de l'élevage (40\%). De 2008 à 2014, une différence significative des activités génératrices de revenus a été observée. Certains villageois ont bénéficié de projets de développement financés par des organismes environnementaux. D'autres ont profité des activités alternatives liées à la conservation de la nature comme la restauration des zones dégradées, I'assistance ou le guidage de chercheurs, l'aménagement des infrastructures, les patrouilles périodiques, I'apiculture ou encore l'élaboration de produits alimentaires et industriels. La plupart des participants ont tions in order to improve the management of the Maromizaha Protected Area.

Groupe d'Etude et de Recherche sur les Primates de Madagascar (GERP), Département de Paléontologie et d'Anthropologie Biologique (DPAB), Faculté des Sciences, Université d'Antananarivo, Madagascar

Groupe d'Etude et de Recherche sur les Primates de Madagascar (GERP), Département de Biologie Animale (DBA), Faculté des Sciences, Université d'Antananarivo, Madagascar

Groupe d'Etude et de Recherche sur les Primates de Madagascar (GERP), Institut Supérieur de Sciences, Environnement et Développement Durable (ISSEDD) Groupe d'Etude et de Recherche sur les Primates de Madagascar (GERP), Département de Gestion, Faculté de DEGS, Université d'Antananarivo, Madagascar Groupe d'Etude et de Recherche sur les Primates de Madagascar (GERP), retraité de la Société Phael-Flor, Ankorahotra, Madagascar.

Groupe d'Etude et de Recherche sur les Primates de Madagascar (GERP), enseignant Chercheur de l'Université de Madagascar, Madagascar. 


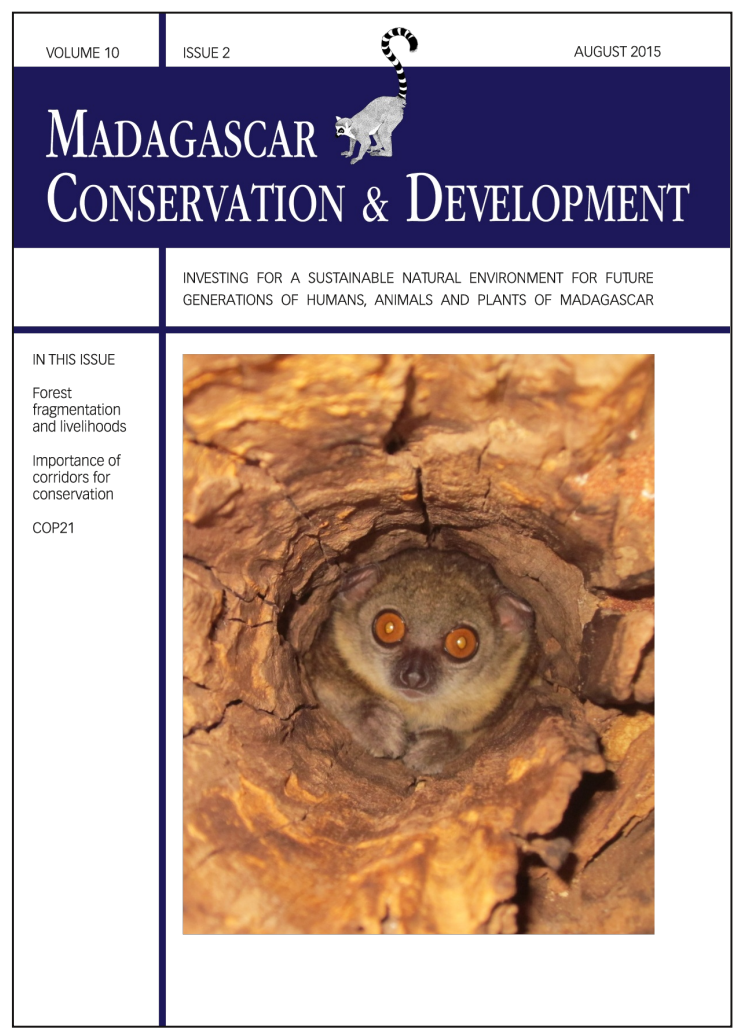

Madagascar Conservation \& Development is the journal of Indian Ocean e-Ink. It is produced under the responsibility of this institution. The views expressed in contributions to MCD are solely those of the authors and not those of the journal editors or the publisher.

All the Issues and articles are freely available at http://www.journalmcd.com

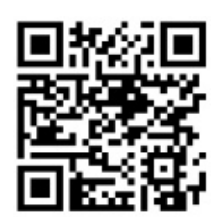

Contact Journal MCD

info@journalmcd.net for general inquiries regarding MCD funding@journalmcd.net to support the journal

Madagascar Conservation \& Development Institute and Museum of Anthropology

University of Zurich

Winterthurerstrasse 190

$\mathrm{CH}-8057$ Zurich

Switzerland

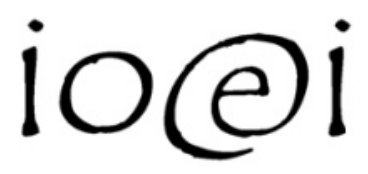

Indian Ocean e-Ink

Promoting African Publishing and Education

www.ioeink.com

Missouri Botanical Garden (MBG)

Madagascar Research and Conservation Program BP 3391

Antananarivo, 101, Madagascar 
conscience des services écologiques rendus par l'aire protégée (94,3\%). Le niveau d'instruction a augmenté de 2008 à 2014, mais même si $56 \%$ ont suivi l'école primaire, $15,6 \%$ des villageois sont analphabètes. Quelques points forts et des limites sont mentionnés et des recommandations sont formulées en vue d'améliorer le système de gestion de l'Aire Protégée de Maromizaha.

\section{INTRODUCTION}

The main goals of the protected area system in Madagascar are to maintain environmental services and the sustainable use of natural resources as a step towards reducing poverty and promoting sustainable development (Office National pour l'Environnement 2006). Beginning in 2003, when the national strategy to expand the protected area network was launched, a number of formerly unprotected sites started to receive conservation attention. Through this process, the management of the Maromizaha forest in eastern Madagascar as a protected area category $\mathrm{VI}$ by the national primate conservation organization Groupe d'Etude et de Recherche sur les Primates de Madagascar (GERP) was approved by the Ministry of Environment and Forests (MEF) in 2008 (Ratsimbazafy et al. 2008). Since then, GERP, together with technical and financial stakeholders, has provided support to the livelihoods of the local people around the Maromizaha Protected Area in order to reduce the dependency on natural resources.

Located in the southeast portion of the Ankeniheny-Zahamena Corridor, Maromizaha forest is characterized by high fauna and flora species richness (Randrianambinina et al. 2006, Rakotozafy 2011, Razafindravony 2014). The majority of the villages in proximity to Maromizaha forest rely on agriculture. Currently, the main threats to Maromizaha forest are the local demand for timber, charcoal production, and the creation of new agricultural lands (Rakotosamimanana et al. 2004). In addition, timber exportation outside the community illegal logging, harvesting of palm heart, and lemur hunting constitute further pressures. Because of these multiple threats, conserving the biodiversity of Maromizaha forest requires a holistic strategy to deliver conservation and development outcomes effectively and sustainably.

Beginning in April 2014, GERP undertook a preliminary assessment of the contribution that conservation of Maromizaha forest makes to the local socio-economic settingandprepared a rapid survey of households in six villages adjacent to Maromizaha forest. The aim of this survey was to evaluate the development support that had been provided to the villages and assess its impact on the main income-generating activities of the local people, compare the highest levels of education completed by study participants in 2014 to the outcome of GERP survey in 2008 at the same villages, and gauge the thinking of study participants about conservation offsetting, in order to establish a 5-year action plan which will encompass conservation, environmental education, sustainable development, and sustainable ecotourism (Office National pour l'Environnement 2002).

\section{STUDY SITE}

The Maromizaha forest is located geographically in latitude $18^{\circ} 57^{\prime} \mathrm{S}$ and $19^{\circ} 00^{\prime} \mathrm{S}$, longitude $48^{\circ} 26^{\prime} \mathrm{E}$ and $48^{\circ} 31^{\prime} \mathrm{E}$, in the Alaotra Mangoro region, Moramanga district and within both the rural municipalities of Andasibe and Ambatovola. There are three main village areas near the forest: Antsapanana, Morafeno and Ambavaniasy (Figure 1). The Maromizaha forest is a 1,880ha expanse of largely contiguous forest located $140 \mathrm{~km}$ east of Antananarivo and

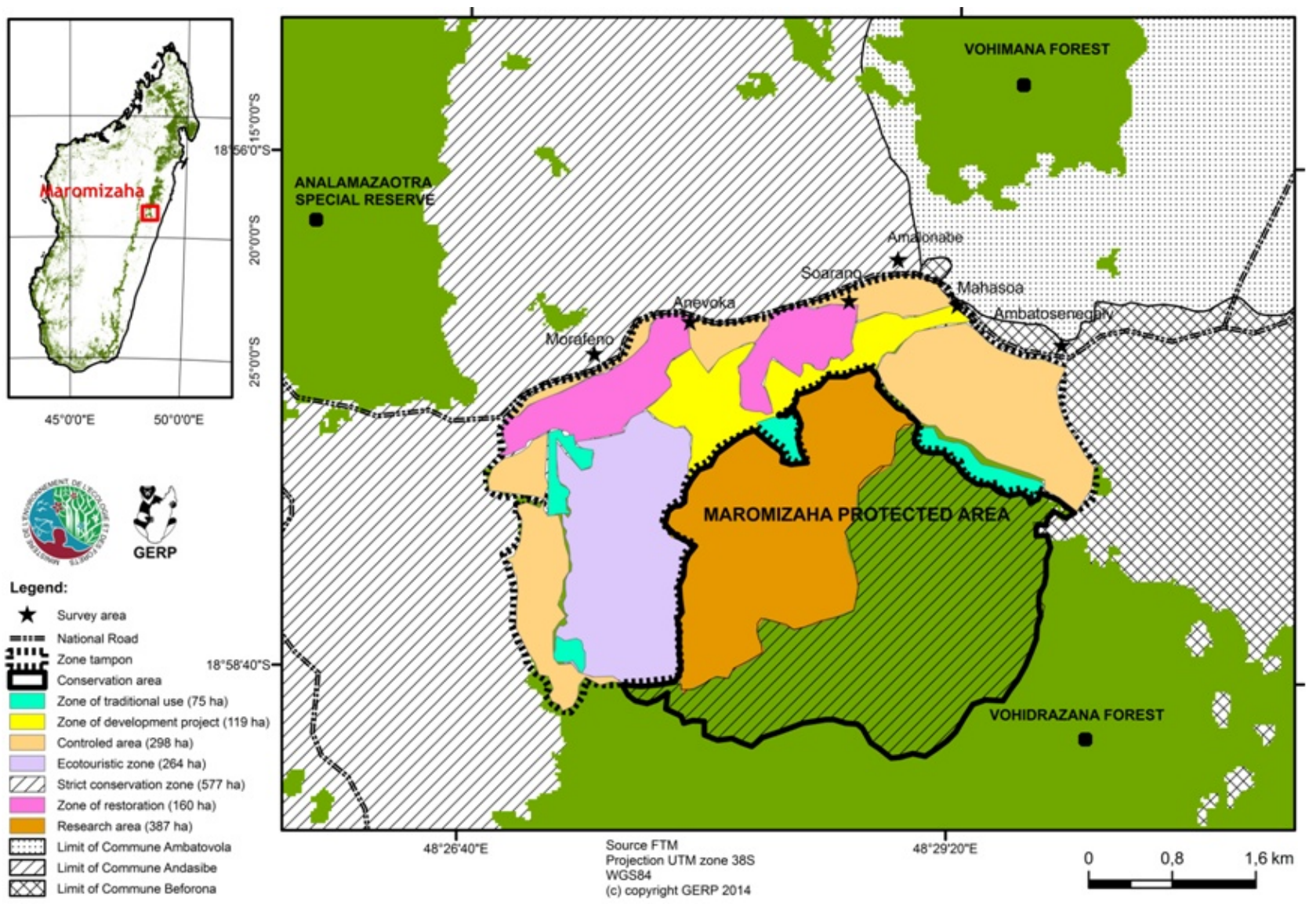

Figure 1. Zones of Maromizaha Protected Area in 2014 
$225 \mathrm{~km}$ from Toamasina. Maromizaha is bordered to the north by the Route Nationale 2, to the east by the Befody hills, to the west by the Madiorano River and to the south by the Ankazomirahavavy River. The forest ranges between elevations of $794 \mathrm{~m}$ and $1224 m$ (Ramanahadray 2009). The Maromizaha forest is surrounded by three forest blocks, including the special Reserve (SR) Analamazaotra to the northwest, Vohimana forest to the northeast and Vohidrazana forest to the east (Figure 1).

\section{METHODOLOGY}

The main research questions of our study are: What was the impact of development support on the main income generating activities of the local people, and within households what was the highest level(s) of education for the years 2008 and 2014? Additionally, we assessed local people's awareness of benefits gained from conservation offsetting.

The methods employed in data collection included the use of filter questions (Rennekamp et al. 2000) as a means to establish the essential questions for the survey and, thereby, gain focused responses (e.g., Question 2: "Is charcoal production your main income-generating activity?" - if "Yes", go to Question 3: "What are the reasons why you practiced charcoal production; if "None", go to Question 4: "What is your main income-generating activity?"; "Was your household a beneficiary of development project?"), and focus groups to discuss the survey (Rennekamp et al. 2000, Moreau et al. 2004).

We visited six villages: Morafeno, Anevoka, Soarano, Amalonabe, Mahasoa, and Ambatosenegaly. In each village, we collaborated with the chief of the village and asked him to look for more than three beneficiaries of the local support project, and meet at a mutually determined location; once gathered, we conducted one or more focus groups with three to nine participants each. For each focus group, we explained the aim of the survey and we asked individuals the same question one by one, taking note of the replies each person made on their survey sheet. All sessions were also tape recorded.

In total, there were ten questions on the survey. Two questions were about the household economic situation; five questions dealt with the main income generating activities of the household. One question was about income management in the household, one question asked for the highest level(s) of education for members of the household, and one question dealt with their cognition of household members regarding the economic advantages of conservation.

For statistical analyses of the survey data, Chi-Square was performed, using GraphPad Prism (graphpad.com/quickcalcs/).

\section{RESULTS AND DISCUSSION}

We interviewed a total of 70 participants from six focus groups in Anevoka, two focus groups in Ambatosenegaly and Morafeno; one focus group was held in each of the villages of Mahasoa, Amalonabe and Soarano. The household size among the six villages varied from one to eight persons, with a mean of $4.2 \pm 1.5$ persons. The main income-generating activities across the six villages for the years 2008 and 2014 were agriculture, live-stock, charcoal production, logging, breaking stones, bee-keeping, fishfarming, selling, and others (handicraft, teaching).

Statistical analyses revealed a significant difference in the main income-generating activities between both years $\left(\chi^{2}=31.62\right.$, $d f=8, p=0.0001$ ). Between the years 2008 and 2014, agriculture
(38.4\% vs. $46.0 \%)$, live-stock (20.0\% vs. $29.4 \%)$, and handicraft and teaching (4.6\% vs.6.4\%) activities had increased, whereas activities such as logging (4.6\% vs. 3.2\%) and stone breaking (6.2\% vs. $5.6 \%$ ), and in particular charcoal production (13.9\% vs. $2.4 \%$ ) had decreased. Most people grew food crops, such as rice, cassava, maize, sweet potatoes, cucumbers, potatoes and beans, whilst a few grew cash crops such as sugar cane, the leaves of ravintsara or Cinnamomum camphora (identification by Razakamalala 2015 In litt., Supplementary Material) for producing essential oils, and ginger.

Since 2008, the local population had the opportunity to get involved in occasional activities (guides,cooks, guards, and porters) during the visit of researchers, students and tourists to the Maromizaha protected area. In addition, forest restoration of the Mantadia-Maromizaha-Zahamena Corridor from 2008 to 2010 benefitted the local population of Maromizaha protected area. One hundred people found jobs as tree planters and nurserymen. In 2012 , the passage of the cyclone Giovanna destroyed food crops and bananas. In 2013, a plague of rats destroyed more food crops of the villagers. Therefore, in 2012 and 2013, the local population was beyond their means to survive.

In 2013, GERP/Global Environment Facility Small Grants Programme Madagascar (GEF-SGP) shared one hundred kilograms of improved seeds of kidney beans with a close collaboration between GERP and the National Center of Applied Research to Rural Development (FOFIFA), fertilizer and three tons of gingers to fifty peasants. This project also provided beehives and honey extractors, as well a professional beekeeper to monitor twenty pilot beekeeping operations for a fortnight.

A bee disease called varois (Varroa sp., Acari: Varroidae), common in the area near the forest of Maromizaha, has been negatively affecting the honey harvested by the farmers since 2011. To combat the disease, beekeepers around Maromizaha forest started using a biological treatment that was shared by a beekeeping specialist. The effective treatment uses the scent of the wild thyme plant (Thymus serpyllum), which has been soaked in a vinegar concentrate.

The study found that in 2014 some people were participating in new income generating activities, such as fish farming and beekeeping. Fish farming was tried and carried out by a small number of individuals $(<2 \%)$. Beekeeping activities and forest protection have been noted to have a mutually beneficial relationship. Maromizaha forest has many benefits for beekeeping when compared to a beekeeping area with Eucalyptus trees. The types of tree species within Maromizaha forest have qualities that improve the honey harvest that beekeepers get from their hives. Smoke from slash and burn agriculture and charcoal ovens are the main enemies of bees, as they force the bee populations to move around and change hives. Because of this, beekeepers are more willing to participate in forest protection and encouraging people to not use charcoal ovens. The incomes generated from honey sales are enough to support the livelihoods of beekeepers.

The rate of auto-consumption of crops was at $100 \%$. Some $44 \%$ of villagers saved at least a part of their income for their children's education. Investing in livestock was done by $21.4 \%$ of people, $18.6 \%$ of people spent income to improve their house (shifting from a traditional to a modern house), while $10.0 \%$ bought furniture.

From 2008 to 2014, illiteracy decreased from almost 40\% to just $13.6 \%$. The percentage of people finishing the final class of 
primary school increased from under $20 \%$ to $25.4 \%$, and those completing the final class of secondary school rose from under $5 \%$ to $8.5 \%$. The difference between 2008 and 2014 in highest level of education achieved was not statistically significant $\left(\chi^{2}=11.98, d f=8, p=0.1521\right)$. Since the development program started in 2008, educational opportunities for children have improved. The study participants noted that they will help support their children through higher school levels, instead of not allowing their children to study.

The 2014 survey results showed that $94.3 \%$ of the participants understood that the forest provides important ecosystem services (e.g., drinking water, fresh air, water for their agriculture, traditional medicine, suitable habitat for wildlife, timbers in the areas of use; Figure 2, Supplementary Material). Only 38.6\% considered conservation offsetting to produce tangible outcomes in terms of employment, while $17.1 \%$ of respondents noted tourism as a benefit from conservation offsetting. In general, the villagers feel that forest protection benefits their communities. The communities already know the laws and regulations regarding forest protection and the consequences of destroying the forest. There are, however, some people who are not permanent community members and who continue to cut down forest and make charcoal in order to generate income. This behavior is not put up with or condoned by long-term community members in the area around Maromizaha. The development programs have incorporated local and traditional authorities to help deal with this problem (Ingram et al.2012)

\section{CONCLUSION}

One strong point of the development work made clear by the study is that the development projects were able to continue through the political turmoil in Madagascar that started in 2009. There were also community members ready and willing to participate in forest protection and modern, effective farming and animal husbandry practices.

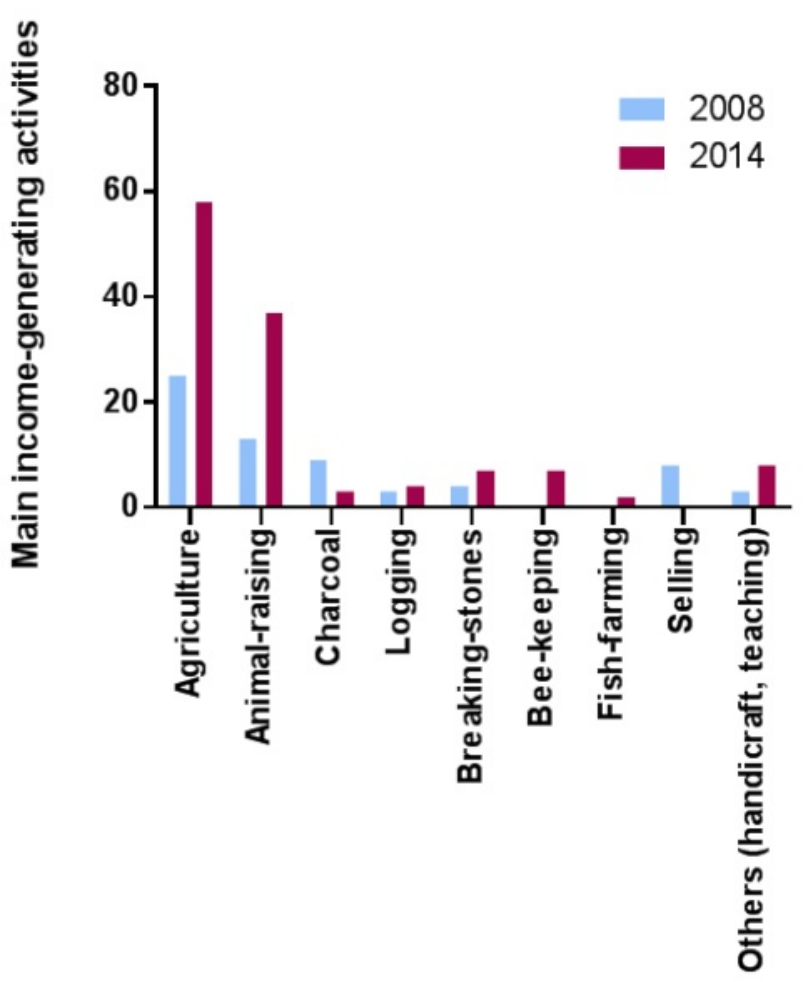

Figure 2. Breakdown of knowledge about the conservation offsetting.
A weakness of the project is that the number of people who are able to participate in the development projects is very small compared to the total number of households in the three communes around the forest. Another weakness or difficulty is promoting behavior change, especially regarding agricultural techniques like slash and burn agriculture.

Furthermore, improvement of materials and supplies needed for the development program to help a large number of community members is possible only by partnering with national initiative and Madagascar investment. These collaborations can help improve the development work around Maromizaha to reach a larger number of people by increasing the quantity of agricultural equipment available to the development project and increasing the frequency and intensity of effective development projects. Also greatly needed is the improvement of partnerships with local authorities in order to decrease and eliminate harmful practices and behaviors such as charcoal production and slash and burn agriculture.

\section{ACKNOWLEDGMENTS}

Our sincere thanks go to the Ministry of Environment, Ecology and Forests for classifying Maromizaha forest as a new protected area. Our gratitude goes to the reviewers and to Chia Tan, Tony King, Steven Goodman, and William Dreyer for suggesting improvements to this manuscript. We also thank the beekeeping technician, Edouard Ranaivo, the traditional and local authorities at Ambavaniasy, Morafeno, and Ampangalatsary located in the Rural Municipality of Andasibe for having provided the access to demographic data and visits to villages. We extend our thanks to Global Environment Facility Small Grants Programme Madagascar (GEF/SGP) for founding the developmental projects, to Missouri Botanical Garden (MBG) in Antananarivo for the "Ravintsara" determination and to Houston Zoo for having funded this socio-economic survey.

\section{REFERENCES}

Ingram, J. C., Redford, H. K. and Watson, E. M. 2012. Applying ecosystem services approaches for biodiversity conservation: benefits and challenges. Survey and Perspectives Integrating, Environment and Society 5, 1: 2-7.

Moreau, A., Dedianne, M.-C., Letrilliart, L., Le Goazio, M.-F., Labarère, J. and Terra, J. L. 2004. S'approprier la méthode du focus group. La Revue du Praticien. Médecine Générale 18, 645: 382-384. Available at <http://ow.ly/MzbbK>

Office Nationale pour l'Environnement. 2002. Stratégie nationale pour la gestion durable de la biodiversité. Ministère de l'Environnement.

Office Nationale pour l'Environnement. 2006. Guide pour la réalisation d'une étude d'impact Environnemental et Social pour les projets de création de Nouvelles Aires Protégées. Ministère de l'Environnement.

Rakotosamimanana, B., Ralaiarison, R. R., Ralisoamalala, R. C., Rasolofoharivelo, T. M. Raharimanantsoa, V. et al. 2004. Comment et pourquoi les lémuriens diurnes disparaissent peu à peu dans les forêts d'Ambato et de Maromizaha (Région de Moramanga) Madagascar? Lemur News 9: 19-24.

Rakotozafy, L. M. S. 2012. Etude de la Communauté des Espèces d'Amphibiens Pandanicoles de la Forêt Humide de Maromizaha, Moramanga. Unpub. DEA en Sciences de la Vie, Option Biologie Ecologie et Conservation animales, Faculté des Sciences, Université d'Antananarivo.

Ramanahadray, S. J. 2009. Etude Ecologique de Différents Types de Formations Végétales de Maromizaha (Corridor Biologique Ankeniheny-Zahamena) : Schéma d'Aménagement et Plan de Gestion. Unpub. DESS de Sciences et Environment: Biologie de Conservation. Faculté des Sciences, Université d'Antananarivo.

Randrianambinina, B. and Rasoloharijaona, S. 2006. Inventaires des lémuriens nocturnes dans la forêt pluviale de Maromizaha (Est de Madagascar). Lemur News 11: 9-12. 
Ratsimbazafy, J., Ralison, J. M., Rabarison, H., Randrianarison, R. M., Manesimana, R. M., Rasolondraibe, L. T., Rasoarivelo, D. S., Andrianasolo, R. M., Rakotosamimanana, T. H. and Andrianandrasana, H. 2008. Préservation de la Biodiversite de Maromizaha. A Conservation Project of the GERP. Unpub. Report.

Razafindravony, L. E. 2014. Etude Comparative du Comportement Alimentaire des Femelles Adultes et des Juvéniles Âgés d'un An d'Indri indri (Gmelin, 1789) dans la Forêt Humide de Maromizaha, Est de Madagascar. Unpub. DEA en Sciences de la Vie, Option Biologie Ecologie et Conservation animales, Faculté des Sciences, Université d'Antananarivo.

Rennekamp, R. A. and Martha A. 2000. Using focus Group in Program Development and Evaluation. UK Cooperative service, University of Kentucky, College of Agriculture: A Practical Guide for Applied research. 3rd Edition.

\section{SUPPLEMENTARY MATERIAL.}

Available online only.

Table S1. Distribution of the population of Morafeno. (Source: 2013 census Morafeno).

Table S2. Location of villages, the number of focus group and participants.

Figure S1. Main income-generating activities of villagers living in and around the Maromizaha Protected Area on the years 2008 and 2014.

Figure S2. Income use of villagers living in and around Maromizaha Protected Area.

Figure S3. Highest level of education completed by study participants.

Figure S4. Breakdown of knowledge about the conservation offsetting.

Figure S5. Ravintsara tree or Cinnamomum camphora, Lauraceae, planted near Maromizaha Protected Area, an allogenous species also known as the camphor tree.

Figure S6. Syntype of Cryptocarya aromatic, Lauraceae, an endemic species in the Lauraceae family, also known in Madagascar by its vernacular name Ravintsara. 